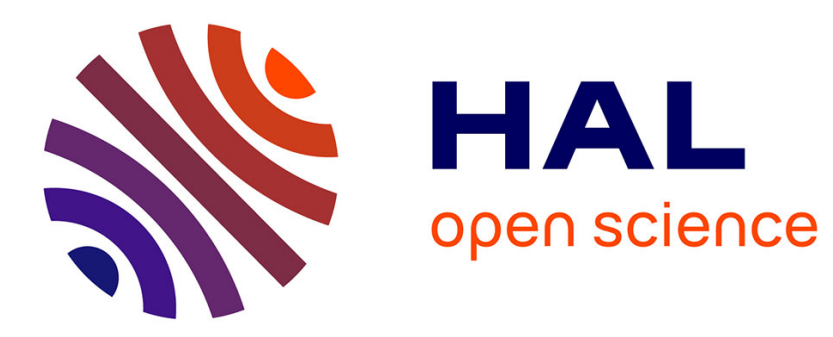

\title{
Editorial - Impact assessment, ecology and management of animal pests affecting field crop establishment: An introduction to the special issue
}

Jay Ram Lamichhane

\section{- To cite this version: \\ Jay Ram Lamichhane. Editorial - Impact assessment, ecology and management of animal pests affect- ing field crop establishment: An introduction to the special issue. Crop Protection, 2021, 150, 24p. 10.1016/j.cropro.2021.105779 . hal-03301902}

\section{HAL Id: hal-03301902 \\ https://hal.inrae.fr/hal-03301902}

Submitted on 27 Jul 2021

HAL is a multi-disciplinary open access archive for the deposit and dissemination of scientific research documents, whether they are published or not. The documents may come from teaching and research institutions in France or abroad, or from public or private research centers.
L'archive ouverte pluridisciplinaire HAL, est destinée au dépôt et à la diffusion de documents scientifiques de niveau recherche, publiés ou non, émanant des établissements d'enseignement et de recherche français ou étrangers, des laboratoires publics ou privés.

\section{(c)(1)}

Distributed under a Creative Commons Attribution| 4.0 International License 


\section{Journal Pre-proof}

Editorial - Impact assessment, ecology and management of animal pests affecting field crop establishment: An introduction to the special issue

Jay Ram Lamichhane

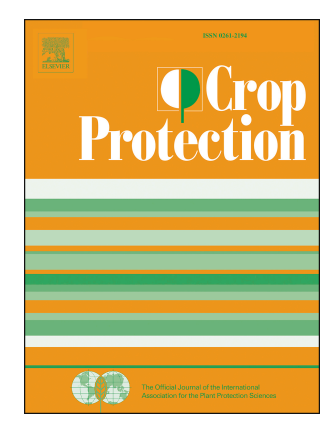

PII:

S0261-2194(21)00249-0

DOI: https://doi.org/10.1016/j.cropro.2021.105779

Reference: JCRP 105779

To appear in: Crop Protection

Received Date: 21 July 2021

Revised Date: 22 July 2021

Accepted Date: 23 July 2021

Please cite this article as: Lamichhane, J.R., Editorial - Impact assessment, ecology and management of animal pests affecting field crop establishment: An introduction to the special issue, Crop Protection (2021), doi: https://doi.org/10.1016/j.cropro.2021.105779.

This is a PDF file of an article that has undergone enhancements after acceptance, such as the addition of a cover page and metadata, and formatting for readability, but it is not yet the definitive version of record. This version will undergo additional copyediting, typesetting and review before it is published in its final form, but we are providing this version to give early visibility of the article. Please note that, during the production process, errors may be discovered which could affect the content, and all legal disclaimers that apply to the journal pertain.

() 2021 Published by Elsevier Ltd. 
Editorial - Impact assessment, ecology and management of animal pests affecting field crop establishment: An introduction to the special issue

Jay Ram Lamichhane*

AGIR, University of Toulouse, INRAE, Castanet-Tolosan, France

\section{${ }^{*}$ For correspondence: jay-ram.lamichhane@inrae.fr(J.R. Lamichhane)}

Keywords: bird damage, emergence failure, post-emergence damage, seed damage, seed predation, seedling damage, seedling losses

\section{The crop establishment phase}

Crop establishment is an early phase that consists of three sub-phases: sowing to seed germination, seed germination to seedling emergence, and seedling emergence to initial competition among young plants (Aubertot et al., 2020; Figure 1). The initial seed and seedling vigor (i.e. the speed of seed germination and seedling emergence; Maguire, (1962)) are a key indicators that determine a rapid, uniform and robust crop establishment across diverse environmental conditions (Finch-Savage and Bassel, 2016; Maguire, 1962).

The quality of field crop establishment can be characterized by the rate of healthy looking young plants compared with the sowing density (Lamichhane et al., 2020b). This means that only a high percentage of final emergence is not sufficient for a crop to successfully establish as a non-optimal initial vigor will result in poor growth with stunted young plants. Resource use efficiency and crop yield depend on successful plant establishment in the field. This is especially true for crops that are not able to compensate pre- and post-emergence damage and/or losses due to several factors (Table 1).

Several biotic (Firake et al., 2016; McKee et al., 2020; Rojas et al., 2016; You and Barbetti, 2017) and abiotic (Bybordi and Tabatabaei, 2009; Wijewardana et al., 2019) factors may lead to a poor quality of crop establishment (Figure 2). This has several direct (e.g. yield losses, additional production costs due to seed purchase and resowing etc.) and indirect (e.g. weed development and increased seedbank that leads to heightened management costs) consequences for growers (Lamichhane et al., 2018).

Crop establishment is affected by five major groups of drivers and their interactions namely seed and seedling characteristics, seedbed components (physical, chemical and biological), weather, cropping systems (Lamichhane et al., 2018), and animal pests coming from outside the seedbed (Lamichhane et al., 2020b). The latter have been increasingly reported to cause post-emergence damage of field crops (Dimitri et al., 2012; Firake et al., 2016; Lamichhane, 2021; McKee et al., 2020; Nasu and Matsuda, 1976). A successful management of animal pests affecting crop establishment requires a systems-level approach that combines a range of disciplines including Agronomy, Biology and Ecology. 


\section{Key animal pests affecting the crop establishment phase}

Vertebrate (e.g. birds, mammals, rodents etc.) and invertebrate (e.g. flea beetles, slugs, maggots, wireworms) pests cause damage to germinating seeds and emerging or emerged seedlings (Figures 3-5). However, the type and extent of their damage depend on the characteristics related to the plot, field, or landscape. Characteristics related to the plot include the plot's size, crop species, sowing date, and tillage type; those related to the field include the extent of crop diversification and presence or absence of natural or semi-natural habitats; and those related to the landscape include residential areas, forests, and annual vegetations.

\section{Introduction to the special issue: Impact assessment, ecology and management of animal pests affecting field crop establishment}

This special issue focuses on vertebrate and invertebrate pests affecting the crop establishment phase. These pests may cause partial or complete crop establishment failure with a huge economic impact for growers. Understanding the biology, ecology and population dynamics of these animal pests and their impact on the establishment quality of a given crop is a first step toward the development of sustainable crop protection measures that can be embedded into an integrated pest management (IPM) framework. The special issue includes seven research articles and one perspective paper, for a total of eight papers, which are grouped into three sections. The following are representative summaries of the articles gathered in this issue.

3.1. Damage assessment, identification and risk predictions of animal pests affecting crop establishment

Post-emergence seedling damage due to birds has become the most important economic problem for sunflower growers in France. Although severe losses of sunflower seedlings have been increasingly reported by growers across the country, no study attempted to date to quantify these losses. Sausse et al. (2021b), conducted a three-year observational study across 206 sunflower fields in two major sunflower production basins of France, and quantitfied the rate of post-emergence seedling damage. The authors found that $98 \%$ of the sunflower fields showed partial or total seedling damage symptoms attributable to birds. In particular, $10 \%$ of the surveyed fields were particularly affected with over $20 \%$ of seedlings completely destroyed. This damage results either in an increased production cost (in the case of resowing) or in significant production losses when no resowings are performed.

Wireworms represent one of the most important soil-dwelling pests from an economic point of view. These pests cause severe damage on crops, especially at the crop establishment phase. The severity of damage due to wireworms has been reported to increase under no-till systems although there is no consensus in the literature in this regard. Furlan et al. (2021b) investigated the effect of conventional versus no-tillage practices on the population dynamics of wireworms and the associated damage in the early growth stages of maize crops over a six-year study period (2011-2016). The authors did not find any significant effect of tillage versus no-till practices on the 
population density of these pests or the associated damage to maize crops at the crop establishment phase. These results are encourgaing for an increased adoption of no-till practices, which provide numerous environmental benefits including reduced soil erosion.

Mice cause significant damage to crops worldwide by digging up and consuming newly planted seeds, or by cutting seedlings and stems, and feeding on developing grains. Under favorable conditions, mice can rapidly increase in abundance to form mouse plagues. Forecasting mice population dynamics can assist management to keep this pest species at tolerable densities. This is important for preventative management of the pest that is sustainable in the long-term compared with reactive management, the latter being most often adopted to date. Wang et al. (2021) developed an iterative modeling approach, involving statistical inference and forecasting data, to predict the population dynamics of the striped field mouse (Apodemus agrarius), an indigenous rodent, in a cropland. This approach allowed to understand the effects of environmental variables (rain, temperature, and crop types) on the pest population dynamics, which, in turn, helped predict population outbreaks at the site level several months before their occurrence. The forecasting approach used by the authors can contribute to planning and deployment of $A$. agrarius management measures and to avoid crop damage.

\subsection{Management of animal pests affecting crop establishment}

Birds' damage to sunflower represents an important problem for growers as it often leads to severe economic losses. No effective management measures exist to date to reduce such damage. Werrell et al. (2021) propose a Sonic Net that broadcasts synthetic sounds at frequencies which purportedly mask or block birds' normal communications. In this way, birds are deprived of essential aural information; they vacate the impacted area for more secure locations beyond the reach of Sonic Net. By testing this device through basic small-plot field experiments, the authors demonstrated the effectiveness of the sonic net that reduced damage to sunflowers by $23 \%$ to $64 \%$ at maturity, depending on field locations. The authors predict that the effect of the Sonic Net treatment may be greater in other crop phases and types, such as in the establishment phase or ground cover crops. Indeed, a relative lack of tall, three-dimensional vegetational structure at the crop establishment phase may allow a more effective spread of the Sonic Net sound offering fewer physical refugia for birds to lower their perceived predation risk. Future studies should test the efficacy of this device on other crops and specifically at the crop establishment phase.

Feral or wild pigs represent one of the most important invasive species that cause severe economic crop losses worldwide. These animal pests may attack a large number of crop species and the crop establishment phase is particularly vulnerable to their attacks. More specifically to maize, feral pigs' damage to this crop mainly occurs immediately following planting as these pests consume the freshly planted and germinated seeds. Protecting the maize seeds or seedlings from feral pigs is important to ensure a good quality of maize establishment. Snow et al. (2021) propose an anthraquinone repellent seed treatment to limit seed and seedling damage due to feral pigs. The authors showed that the repellency rate was affected by the concentration of anthraquinone used and that treating the maize seed with $3 \%$ anthraquinone resulted in 
the greatest reduction in damage. Testing of this method under a wide range of field conditions and monitoring for the damage rate as well as the duration of protection offered by this seed treatment method may provide further insights into the usefulness of this method for growers to limit feral pig damage to maize. Nevertheless, unlike in the US, the use of this product is forbidden in many countries including those of the European Union.

Identification of the potential risk factors triggering animal pest damage to maize seedlings and an accurate assessment of seedling losses represent the first step towards integrated management of animal pests affecting the crop establishment phase. Furlan et al. (2021a) through a long-term field survey, identified plant-attacking bird species, agronomic characteristics, cultural practices, and landscape variables, such as the presence of roosting areas. The authors determined that corvids were the most important animal pests affecting maize crop establishment and that no-till practice increased the damage severity compared with minimum and conventional tillage systems. By using a multifactorial model, they highlighted that the presence of roosting areas around the field plots was the most important risk factor that increased damage risk up to five-fold. Seed coatings using chemical (methiocarb and ziram) and biological (ScudoSeed $\AA$ and Eurodif $\AA$ ) bird repellents effectively reduced the risk of corvid damage to maize seedlings. Although the biological bird repellents were less effective than their chemical counterparts in reducing seedling damage due to corvids, the former kept the damage below the 15\% threshold level. The authors conclude that integration of biological bird repellents into IPM principles may result a viable option for growers to limit corvids' damage to maize seedlings under high risk situations.

Vegetation management can be an important agronomic lever to reduce seedling damage due to animal pests. Damage to maize seedlings by rodents, birds and insects, such as stem-cutting termites, represents an important production constraint for growers in central Cameroon. Norgrove (2021) investigated the potential effect of different vegetation management techniques, namely chemical vs. manual weed management and mulching vs. removal of vegetation residues through burning, on maize seedling damage by these animal pests. The author showed that the presence or absence of vegetation cover influenced different types of animal pests affecting maize establishment. Seedling damage due to termites significantly increased in the absence of vegetation while the damage due to birds markedly decreased in the same situation. The removal of vegetation, which represents food sources for insects, via chemical weeding or burning, was the key reason triggering insect attacks to living plants. This emphasizes the importance of vegetation cover, including the presence of weed flora, in natural pest regulations via an improved food source provisioning.

3.3. Challenges and opportunities for the management of animal pests affecting crop establishment

Bird damage to crops in general and that at the crop establishment phase, in particular, has become an important problem for growers. While severe bird damage at the maturity phase occurs in North and South America, bird damage has become an emergeing problem at the establishment phase of spring-sown crops in France and other European countries. However, crop losses due to birds have drawn only little 
attention from the policy side resulting in poor research in these countries. As a consequence, limited bird management tools have been developed and tested to date. This has led to an impasse where the economic sustainability of growing spring crops has been increasingly challenged. Faced with this uncertainity, growers tend to partially or completly abandon crops such as sunflower from their cropping systems by replacing them with other crops that are less likey to suffer bird damage. Sausse et al. (2021a) discuss key contemporary challenges and opportunities for the management of bird damage to crops. The authors highlight the need to adopt data intensive and multiscale approaches to develop effective solutions for bird management and call for networking to tackle this issue.

\section{Conclusions and perspectives}

Damage by animal pests at the crop establishment phase represents an important problem for growers although the frequency and intensity of the damage may widely vary in space and time. More specifically to arable crops, seed and seedling damage due to animal pests has become an emerging problem for some crops such as sunflower, maize, and soybean. However, the solution to this problem, especially that due to birds, is increasingly difficult due to a number of issues as highlighted by Sausse et al. (2021a). In addition, because many bird species provide both ecosystem services and disservices, it is difficult to consider them only as "a pest», which further complicates their management. For example, vertebrate pests such as birds and bats act as natural predators of several crop pests (Sow et al., 2020).

Research and policy should come together with an increasing effort on networking at local, regional, national and international levels. This will help in developing sustainable management solutions that can limit animal pests' damage at the crop establishment phase. More specifically to research, three key priorities can be identified for future: i) an economic estimation of yield losses in monetary terms due to animal pests' damage at the crop establishment phase; ii) an increased effort on the development and testing of methods and/or tools and their robust economic analysis in terms of costeffectiveness; and iii) a larger scale testing of the effectiveness of newly developed tools and/or methods, especially when they are used in combination with other management strategies, as part of IPM.

\section{Acknowledgements}

I thank the reviewers of this special issue, who collaborated with me to ensure timely publication of the issue, and Stephen N. Wegulo for his feedback on this editorial. JRL is partly supported by the Ecophyto Dephy Expe FAST, PSPC Naturellement Pop-corn, and UMT PACTOLE. 


\section{References}

Abati, J., Brzezinski, C.R., Foloni, J., Zucareli, C., Bassoi, M., Henning, F., 2017. Seedling emergence and yield performance of wheat cultivars depending on seed vigor and sowing density. Seed Sci. 39, 58-65.

Aubertot, J.-N., Deguine, J.-P., Lamichhane, J.R., Robin, M.-H., Sarthou, J.-P., Steinberg, C., 2020. Vers une protection agroécologique des cultures en phase d'implantation, in: Réussir l'implantation Des Cultures. pp. 107-134.

Baligar, V.C., Fageria, N.K., 2007. Agronomy and Physiology of Tropical Cover Crops. J. Plant Nutr. 30, 1287-1339. https://doi.org/10.1080/01904160701554997

Blunk, S., Bussell, J., Sparkes, D., de Heer, M.I., Mooney, S.J., Sturrock, C.J., 2021. The effects of tillage on seed-soil contact and seedling establishment. Soil Tillage Res. 206, 104757. https://doi.org/https://doi.org/10.1016/j.still.2020.104757

Boiffin, J., Durr, C., Fleury, A., Marinlafleche, A., Maillet, I., 1992. Analysis of the variability of sugar-beet (Beta vulgaris L.) growth during the early stages. Agronomie 12, 515525.

Boureima, S., Eyletters, M., Diouf, M., Diop, T., Damme, P., 2011. Sensitivity of seed germination and seedling radicle growth to drought stress in Sesame (Sesamum indicum L.). Res. J. Environ. Sci. 5, 557-564.

Brandsæter, L.O., Smeby, T., Tronsmo, A.M., Netland, J., 2000. Winter Annual Legumes for Use as Cover Crops in Row Crops in Northern Regions: II. Frost Resistance Study. Crop Sci. 40, 175-181. https://doi.org/https://doi.org/10.2135/cropsci2000.401175x

Bybordi, J., Tabatabaei, J., 2009. Effect of salinity stress on germination and seedling properties in canola cultivars (Brassica napus L.). Not. Bot. Horti Agrobot. ClujNapoca 37, 71-76.

Carabajal-Capitán, S., Kniss, A.R., Jabbour, R., 2021. Seed Predation of Interseeded Cover Crops and Resulting Impacts on Ground Beetles. Environ. Entomol. https://doi.org/10.1093/ee/nvab026

Chen, C., Jackson, G., Neill, K., Wichman, D., Johnson, G., Johnson, D., 2005. Determining the Feasibility of Early Seeding Canola in the Northern Great Plains. Agron. J. 97, 1252-1262. https://doi.org/https://doi.org/10.2134/agronj2005.0004

De Ron, A.M., Rodiño, A.P., Santalla, M., González, A.M., Lema, M.J., Martín, I., Kigel, J., 2016. Seedling Emergence and Phenotypic Response of Common Bean Germplasm to Different Temperatures under Controlled Conditions and in Open Field. Front. Plant Sci. 7, 1087. https://doi.org/10.3389/fpls.2016.01087

del Moral, M.B.G., del Moral, L.F.G., 1995. Tiller production and survival in relation to grain yield in winter and spring barley. F. Crop. Res. 44, 85-93. https://doi.org/https://doi.org/10.1016/0378-4290(95)00072-0

Dimitri, G., Yuri, V., Albores-Barajas, N., Emilio, B., Lorenzo, V., Cecilia, S., 2012. Feral Pigeons: Problems, Dynamics and Control Methods, Integrated PestManagement 
and Pest Control Current and Future Tactics Dr. Sonia Soloneski(Ed.), ISBN: 978953-51-0050-8, InTech,.

Douglas, J., Macfadyen, S., Hoffmann, A., Umina, P., 2017. Crop Seedling Susceptibility to Armadillidium vulgare (Isopoda: Armadillidiidae) and Ommatoiulus moreletii (Diplopoda: Iulidae). J. Econ. Entomol. 110, 2679-2685. https://doi.org/10.1093/jee/tox275

Douglas, M.R., Tooker, J.F., 2012. Slug (Mollusca: Agriolimacidae, Arionidae) Ecology and Management in No-Till Field Crops, With an Emphasis on the mid-Atlantic Region. J. Integr. Pest Manag. 3, C1-C9. https://doi.org/10.1603/IPM11023

Dürr, C., Aubertot, J.-N., 2000. Emergence of seedlings of sugar beet (Beta vulgaris L.) as affected by the size, roughness and position of aggregates in the seedbed. Plant Soil 219, 211-220. https://doi.org/10.1023/A:1004723901989

Ebregt, E., Struik, P.C., Odongo, B., Abidin, P.E., 2005. Pest damage in sweet potato, groundnut and maize in north-eastern Uganda with special reference to damage by millipedes (Diplopoda). NJAS - Wageningen J. Life Sci. 53, 49-69. https://doi.org/https://doi.org/10.1016/S1573-5214(05)80010-7

Fageria, N.K., 2007. Yield Physiology of Rice. J. Plant Nutr. 30, 843-879. https://doi.org/10.1080/15226510701374831

Finch-Savage, W.E., Bassel, G.W., 2016. Seed vigour and crop establishment: Extending performance beyond adaptation. J. Exp. Bot. https://doi.org/10.1093/jxb/erv490

Firake, D.M., Behere, G.T., Chandra, S., 2016. An environmentally benign and costeffective technique for reducing bird damage to sprouting soybean seeds. F. Crop. Res. 188, 74-81. https://doi.org/https://doi.org/10.1016/j.fcr.2016.01.008

Furlan, L., Contiero, B., Chiarini, F., Bottazzo, M., Milosavljević, I., 2021a. Risk factors and strategies for integrated management of bird pests affecting maize establishment. Crop Prot. 105744. https://doi.org/https://doi.org/10.1016/j.cropro.2021.105744

Furlan, L., Milosavljević, I., Chiarini, F., Benvegnù, I., 2021b. Effects of conventional versus no-tillage systems on the population dynamics of elaterid pests and the associated damage at establishment of maize crops. Crop Prot. 105751. https://doi.org/https://doi.org/10.1016/j.cropro.2021.105751

Gallardo-Carrera, A., Léonard, J., Duval, Y., Dürr, C., 2007. Effects of seedbed structure and water content at sowing on the development of soil surface crusting under $\begin{array}{llll}\text { rainfall. Soil Tillage 207-217. } & \end{array}$ https://doi.org/https://doi.org/10.1016/j.still.2007.01.001

Gan, Y.T., Miller, P.R., Liu, P.H., Stevenson, F.C., McDonald, C.L., 2002. Seedling emergence, pod development, and seed yields of chickpea and dry pea in a semiarid environment. Can. J. Plant Sci. 82, 531-537. https://doi.org/10.4141/P01-192

Hossain, Z., Johnson, E.N., Wang, L., Blackshaw, R.E., Cutforth, H., Gan, Y., 2019. Plant establishment, yield and yield components of Brassicaceae oilseeds as potential biofuel feedstock. Ind. Crops Prod. 141, 111800. https://doi.org/https://doi.org/10.1016/j.indcrop.2019.111800

Huang, Y., Zhang, Z., Nan, Z., Unkovich, M., Coulter, J.A., 2021. Effects of cultivar and 
growing degree day accumulations on forage partitioning and nutritive value of common vetch (Vicia sativa L.) on the Tibetan plateau. J. Sci. Food Agric. n/a. https://doi.org/https://doi.org/10.1002/jsfa.11006

Kirby, E.J.M., 1993. Effect of sowing depth on seedling emergence, growth and development in barley and wheat. F. Crop. Res. 35, 101-111. https://doi.org/https://doi.org/10.1016/0378-4290(93)90143-B

Lamhamdi, M., El Galiou, O., Bakrim, A., Nóvoa-Muñoz, J.C., Arias-Estévez, M., Aarab, A., Lafont, R., 2013. Effect of lead stress on mineral content and growth of wheat (Triticum aestivum) and spinach (Spinacia oleracea) seedlings. Saudi J. Biol. Sci. 20, 29-36. https://doi.org/https://doi.org/10.1016/j.sjbs.2012.09.001

Lamichhane, J.R., 2021. Post-emergence seedling damage due to vertebrate pests and its impact on soybean establishment. PeerJ 9:e11106, https://doi.org/10.7717/peerj.11106.

Lamichhane, J.R., Aubertot, J.-N., 2021. Effect of early and conventional sowings on soybean establishment quality, nodulation and early biomass development under inoculation with Rhizoctonia solani. PhytoFrontiers ${ }^{\mathrm{TM}}$. https://doi.org/10.1094/PHYTOFR-12-20-0046-R

Lamichhane, Jay Ram, Aubertot, J.-N., Champolivier, L., Debaeke, P., Maury, P., 2020a. Combining Experimental and Modeling Approaches to Understand Genotype $\mathrm{x}$ Sowing Date $\mathrm{x}$ Environment Interaction Effects on Emergence Rates and Grain Yield of Soybean. Front. Plant Sci. https://doi.org/org/10.3389/fpls.2020.558855

Lamichhane, J R, Constantin, J., Schoving, C., Maury, P., Debaeke, P., Aubertot, J.-N., Dürr, C., 2020. Analysis of soybean germination, emergence, and prediction of a possible northward establishment of the crop under climate change. Eur. J. Agron. 113, 125972. https://doi.org/10.1101/632976

Lamichhane, J.R., Debaeke, P., Steinberg, C., You, M.P., Barbetti, M.J., Aubertot, J.-N., 2018. Abiotic and biotic factors affecting crop seed germination and seedling emergence: a conceptual framework. Plant Soil 432, 1-28. https://doi.org/10.1007/s11104018-3780-9

Lamichhane, Jay Ram, You, M.P., Barbetti, M.J., Aubertot, J.-N., 2020b. Crop Establishment SIMulator: a qualitative aggregative model to predict the role of phytobiomes on field crop establishment. Phytobiomes J. 4, 327-339. https://doi.org/10.1094/PBIOMES-05-20-0036-R

Liu, W., Tollenaar, M., Stewart, G., Deen, W., 2004. Response of Corn Grain Yield to Spatial and Temporal Variability in Emergence. Crop Sci. 44, 847-854. https://doi.org/10.2135/cropsci2004.8470

Loose, L.H., Heldwein, A.B., Lucas, D.D.P., Hinnah, F.D., Bortoluzzi, M.P., 2017. Sunflower emergence and initial growth in soil with water excess. J. Brazilian Assoc. Agric. Eng. 37, 644-655.

López-Bellido, F.J., López-Bellido, L., López-Bellido, R.J., 2005. Competition, growth and yield of faba bean (Vicia faba L.). Eur. J. Agron. 23, 359-378. https://doi.org/https://doi.org/10.1016/j.eja.2005.02.002 
Maguire, J.D., 1962. Speed of Germination-Aid In Selection And Evaluation for Seedling Emergence And Vigor. Crop Sci. 2, cropsci1962.0011183X000200020033x. https://doi.org/https://doi.org/10.2135/cropsci1962.0011183X000200020033x

Mahdi, L., Bell, C.J., Ryan, J., 1998. Establishment and yield of wheat (Triticum turgidum L.) after early sowing at various depths in a semi-arid Mediterranean environment. F. Crop. Res. 58, 187-196. https://doi.org/https://doi.org/10.1016/S03784290(98)00094-X

Maranville, J.W., Clegg, M.D., 1977. Influence of Seed Size and Density on Germination, Seedling Emergence, and Yield of Grain Sorghum. Agron. J. 69, 329-330. https://doi.org/10.2134/agronj1977.00021962006900020032x

Marshall, A.H., Lewis, D.N., 2004. Influence of seed storage conditions on seedling emergence, seedling growth and dry matter production of temperate forage grasses. Seed Sci. Technol. 32, 493-501.

McKee, S., Anderson, A., Carlisle, K., Shwiff, S.A., 2020. Economic estimates of invasive wild pig damage to crops in 12 US states. Crop Prot. 132, 105105. https://doi.org/https://doi.org/10.1016/j.cropro.2020.105105

McMaster, G.S., Buchleiter, G.W., Bausch, W.C., 2012. Relationships between Sunflower Plant Spacing and Yield: Importance of Uniformity in Spacing. Crop Sci. 52, 309319. https://doi.org/10.2135/cropsci2010.10.0572

Nasu, H., Matsuda, L., 1976. The damage to soybean by pigeons and doves and itscontrol methods. Agr. Hort. 51, 563-566.

Norgrove, L., 2021. Trade-offs in maize seedling losses in African grasslands. Crop Prot. 146, 105676. https://doi.org/https://doi.org/10.1016/j.cropro.2021.105676

Peltonen-Sainio, P., Järvinen, P., 1995. Seeding rate effects on tillering, grain yield, and yield components of oat at high latitude. F. Crop. Res. 40, 49-56. https://doi.org/https://doi.org/10.1016/0378-4290(94)00089-U

Pescador, D.S., Sánchez, A.M., Luzuriaga, A.L., Sierra-Almeida, A., Escudero, A., 2018. Winter is coming: plant freezing resistance as a key functional trait for the assembly of annual Mediterranean communities. Ann. Bot. 121, 335-344. https://doi.org/10.1093/aob/mcx166

Raveneau, M.P., Coste, F., Moreau-Valancogne, P., Lejeune-Hénaut, I., Durr, C., 2011. Pea and bean germination and seedling responses to temperature and water potential. Seed Sci. Res. 21, 205-213. https://doi.org/10.1017/S0960258511000067

Rojas, J.A., Jacobs, J.L., Napieralski, S., Karaj, B., Bradley, C.A., Chase, T., Esker, P.D., Giesler, L.J., Jardine, D.J., Malvick, D.K., Markell, S.G., Nelson, B.D., Robertson, A.E., Rupe, J.C., Smith, D.L., Sweets, L.E., Tenuta, A.U., Wise, K.A., Chilvers, M.I., 2016. Oomycete Species Associated with Soybean Seedlings in North America-Part II: Diversity and Ecology in Relation to Environmental and Edaphic Factors. Phytopathology 107, 293-304. https://doi.org/10.1094/PHYT0-04-16-0176-R

Sausse, C., Baux, A., Bertrand, M., Bonnaud, E., Canavelli, S., Destrez, A., Klug, P.E., Olivera, L., Rodriguez, E., Tellechea, G., Zuil, S., 2021a. Contemporary challenges and opportunities for the management of bird damage at field crop establishment. Crop 
Prot. 148, 105736. https://doi.org/https://doi.org/10.1016/j.cropro.2021.105736

Sausse, C., Chevalot, A., Lévy, M., 2021b. Hungry birds are a major threat for sunflower $\begin{array}{llll}\text { seedlings in } & \text { France. }\end{array}$ https://doi.org/https://doi.org/10.1016/j.cropro.2021.105712

Serrano, M., Robertson, A.E., 2018. The effect of cold stress on damping-off of soybean caused by Pythium sylvaticum. Plant Dis. 102, 2194-2200. https://doi.org/10.1094/PDIS-12-17-1963-RE

Siddique, K.H.M., Loss, S.P., Regan, K.L., Pritchard, D.L., 1998. Adaptation of lentil (Lens culinaris Medik) to short season Mediterranean-type environments: response to sowing rates. Aust. J. Agric. Res. 49, 1057-1066.

Snow, N.P., Halseth, J.M., Werner, S.J., VerCauTeren, K.C., 2021. Anthraquinone Repellent Seed Treatment on Corn Reduces Feeding by Wild Pigs. Crop Prot. 105570. https://doi.org/https://doi.org/10.1016/j.cropro.2021.105570

Souty, N., Rode, C., 1993. Emergence of sugar beet seedlings from under different $\begin{array}{lllll}\text { obstacles. } & \text { Eur. J. Agron. 213-221. }\end{array}$ https://doi.org/https://doi.org/10.1016/S1161-0301(14)80131-7

Sow, A., Seye, D., Faye, E., Benoit, L., Galan, M., Haran, J., Brévault, T., 2020. Birds and bats contribute to natural regulation of the millet head miner in tree-crop agroforestry $\begin{array}{llll}\text { systems. } & \text { Crop } & \text { Prot. } & \end{array}$ https://doi.org/https://doi.org/10.1016/j.cropro.2020.105127

Tridevi, M.K., Branton, A., Trivedi, D., Nayak, G., Mondal, S.C., Jana, S., 2015. Mahendra Kumar Trivedi, Evaluation of plant growth, yield and yield attributes of biofield energy treated mustard (Brassica juncea) and chick pea (Cicer arietinum) seeds. Agric. For. Fish. 4, 291-295.

Tschumi, M., Ekroos, J., Hjort, C., Smith, H.G., Birkhofer, K., 2018. Rodents, not birds, dominate predation-related ecosystem services and disservices in vertebrate communities of agricultural landscapes. Oecologia 188, 863-873. https://doi.org/10.1007/s00442-018-4242-z

Vander Zaag, P., Demagante, A.L., Ewing, E.E., 1990. Influence of plant spacing on potato (Solanum tuberosum L.) morphology, growth and yield under two contrasting environments. Potato Res. 33, 313-323. https://doi.org/10.1007/BF02359305

Vea, E. V, Eckenrode, C.J., 1976. Seed Maggot Injury on Surviving Bean Seedlings Influences Yield12. J. Econ. Entomol. 69, 545-547. https://doi.org/10.1093/jee/69.4.545

Wang, D., Anderson, D.P., Li, K., Guo, Y., Yang, Z., Pech, R.P., 2021. Predicted population dynamics of an indigenous rodent, Apodemus agrarius, in an agricultural system. $\begin{array}{lll}\text { Crop } & \text { Prot. 147, } & 105683 .\end{array}$ https://doi.org/https://doi.org/10.1016/j.cropro.2021.105683

Werrell, A.K., Klug, P.E., Lipcius, R.N., Swaddle, J.P., 2021. A Sonic Net reduces damage to sunflower by blackbirds (Icteridae): Implications for broad-scale agriculture and $\begin{array}{lllll}\text { crop establishment. } & \text { Crop Prot. 144, }\end{array}$ https://doi.org/https://doi.org/10.1016/j.cropro.2021.105579 
432
Wijewardana, C., Reddy, K.R., Krutz, L.J., Gao, W., Bellaloui, N., 2019. Drought stress has transgenerational effects on soybean seed germination and seedling vigor. PLoS One 14,1-20. https://doi.org/10.1371/journal.pone.0214977

Yasumoto, S., Terakado, Y., Matsuzaki, M., Okada, K., 2011. Effects of High Water Table and Short-Term Flooding on Growth, Yield, and Seed Quality of Sunflower. Plant Prod. Sci. 14, 233-248. https://doi.org/10.1626/pps.14.233

You, M.P., Barbetti, M.J., 2017. Severity of phytophthora root rot and pre-emergence damping-off in subterranean clover influenced by moisture, temperature, nutrition, soil type, cultivar and their interactions. Plant Pathol. 66, 1162-1181. https://doi.org/10.1111/ppa.12655

You, M.P., Guo, K., Nicol, D., Kidd, D., Ryan, M.H., Foster, K., Barbetti, M.J., 2017. Cultivation offers effective management of subterranean clover damping-off and root disease. Grass Forage Sci. 72, 785-793. https://doi.org/10.1111/gfs.12282

Zaman, M.S., Malik, A.I., Kaur, P., Erskine, W., 2018. Waterlogging tolerance of pea at germination. J. Agron. Crop Sci. 204, 155-164. https://doi.org/https://doi.org/10.1111/jac.12230 
Table 1. Ability of field crops to compensate pre- and post-emergence losses and potential correlation between the quality of field crop establishment and yield

\begin{tabular}{|c|c|c|c|c|c|}
\hline Crop type & Crop & $\begin{array}{c}\text { Pre- \& post- } \\
\text { emergence losses } \\
\text { compensation ability }\end{array}$ & Compensation method & $\begin{array}{l}\text { Potential correlation } \\
\text { between crop } \\
\text { establishment quality } \\
\text { and yield* } \\
\end{array}$ & References \\
\hline \multirow[t]{6}{*}{ Straw cereals } & Barley & Yes & Tillering & No & del Moral and del Moral (1995) \\
\hline & Oat & Yes & Tillering & No & Peltonen-Sainio and Järvinen (1995) \\
\hline & Wheat & Yes & Tillering & No & Abati et al. (2017) \\
\hline & Sorghum & Yes & Tillering & No & Maranville and Clegg (1977) \\
\hline & Maize & No & Nil & Often positive $\pi$ & Liu et al. (2004) \\
\hline & Rice & Yes & Tillering & No & Fageria (2007) \\
\hline \multirow[t]{5}{*}{ Pulse crops } & Common bean & Yes & SDG, IG, B & No & De Ron et al. (2016); Raveneau et al. (2011) \\
\hline & Pea & Yes & SDG, IG, B & No & Gan et al. (2002); Raveneau et al. (2011) \\
\hline & Lentil & Yes & SDG, IG, B & No & Siddique et al. (1998) \\
\hline & Chickpea & Yes & SDG, IG, B & No & (Gan et al., 2002) \\
\hline & Faba bean & Yes & SDG, IG, B & No & López-Bellido et al. (2005) \\
\hline \multirow[t]{3}{*}{ Oleaginuous crops } & Sunflower & No & Nil & Often positive $\pi$ & McMaster et al. (2012) \\
\hline & Oilseed rape & Yes & Branching & No & Hossain et al. (2019) \\
\hline & Soybean & Yes & SDG, IG, B & No & Lamichhane et al. (2020a) \\
\hline \multirow[t]{2}{*}{ Root and tuber crops } & Sugar beet & No & Nil & Often positive $\pi$ & Boiffin et al. (1992); Souty and Rode (1993) \\
\hline & Potato & Yes & Branching & No & Vander Zaag et al. (1990) \\
\hline Cover crops & $\begin{array}{c}\text { Asteraceae, } \\
\text { Brassicaceae, } \\
\text { Fabaceae, } \\
\text { Hydrophylaceae, } \\
\text { Poaceae, } \\
\text { Polygonaceae }\end{array}$ & Most of them yes & SDG, IG, B & NA & $\begin{array}{l}\text { Baligar and Fageria (2007); Huang et al. } \\
\text { (2021); Marshall and Lewis (2004); Tridevi } \\
\text { et al. (2015) }\end{array}$ \\
\hline
\end{tabular}

SDG: Semi-determinate growth; IG: indeterminate growth; B: branching; NA: not applicable; \#Dependent on crop species and growth conditions 
*The correlation depends on several factors including water availability, soil fertility, maturity rating, planting date and row spacing. A high heterogeneity in emergence date is detrimental to yield for certain crops as plants emerging late relative to neighboring plants provided reduced yield.

ॠWhen the number of individuals per area is increased beyond the optimum plant density, there is a series of consequences that are detrimental to yield 
Table 2. A visual disgnostic key describing major causes affecting crop establishment and descriptions of their symptoms/ characteristics

\begin{tabular}{|c|c|c|c|c|c|}
\hline Sub-phase & \multicolumn{3}{|c|}{ Symptoms or characteristics } & Causes of no crop establishment & References \\
\hline \multirow{3}{*}{$\begin{array}{l}\text { Sowing - seed } \\
\text { germination }\end{array}$} & \multirow{3}{*}{$\begin{array}{l}\text { Seeds fail to } \\
\text { germinate (pre- } \\
\text { germination) }\end{array}$} & \multirow{2}{*}{$\begin{array}{l}\text { Absence of the intact } \\
\text { seed or presence of } \\
\text { seed parts }\end{array}$} & No presence of seed or seed parts & $\begin{array}{l}\text { Technical problem of sowing or } \\
\text { predation of seeds by pests* }\end{array}$ & $\begin{array}{l}\text { Carabajal-Capitán et al. } \\
\text { (2021); Tschumi et al. } \\
\text { (2018) }\end{array}$ \\
\hline & & & $\begin{array}{l}\text { Outer seed coat altered, presence } \\
\text { of empty seed coat }\end{array}$ & $\begin{array}{l}\text { Damage caused by granivores (e.g. } \\
\text { slugs, earthworms or rodents) }\end{array}$ & $\begin{array}{l}\text { Carabajal-Capitán et al. } \\
\text { (2021); Tschumi et al. } \\
\text { (2018) }\end{array}$ \\
\hline & & \multirow{4}{*}{$\begin{array}{l}\text { Presence of non- } \\
\text { germinated and } \\
\text { germinated seeds }\end{array}$} & $\begin{array}{l}\text { Intact seed content but no } \\
\text { germination }\end{array}$ & $\begin{array}{l}\text { Abiotic stress (heat water or } \\
\text { mechanical) or dormancy problem or } \\
\text { seed death }\end{array}$ & $\begin{array}{l}\text { Lamichhane and } \\
\text { Aubertot (2021) }\end{array}$ \\
\hline \multirow{3}{*}{$\begin{array}{l}\text { Seed germination } \\
\text { - seedling } \\
\text { emergence }\end{array}$} & \multirow{3}{*}{$\begin{array}{l}\text { Seedlings fail to } \\
\text { emerge (pre- } \\
\text { emergence) }\end{array}$} & & $\begin{array}{l}\text { Rotten seed content and no } \\
\text { germination }\end{array}$ & $\begin{array}{l}\text { Pre-emergence damping-off (seed- } \\
\text { and soil-borne pathogens) }\end{array}$ & You and Barbetti (2017) \\
\hline & & & $\begin{array}{l}\text { Presence of holes or larvae in or } \\
\text { around seeds }\end{array}$ & $\begin{array}{l}\text { Soil-borne pests (e.g. seed maggots, } \\
\text { wireworms, symphylans, millipedes) }\end{array}$ & Ebregt et al. (2005) \\
\hline & & & $\begin{array}{l}\text { Occurrence of germination but no } \\
\text { emergence, twisted seedlings, } \\
\text { abnormal radicle growth, absence } \\
\text { of necrosis and/or rot, presence } \\
\text { of crust and/or soil compaction in } \\
\text { the seedbed }\end{array}$ & $\begin{array}{l}\text { Mechanical stress such as soil } \\
\text { compaction, soil crust formation }\end{array}$ & $\begin{array}{l}\text { Gallardo-Carrera et al. } \\
\text { (2007); Lamichhane et } \\
\text { al. (2020); Lamichhane } \\
\text { and Aubertot (2021) }\end{array}$ \\
\hline
\end{tabular}




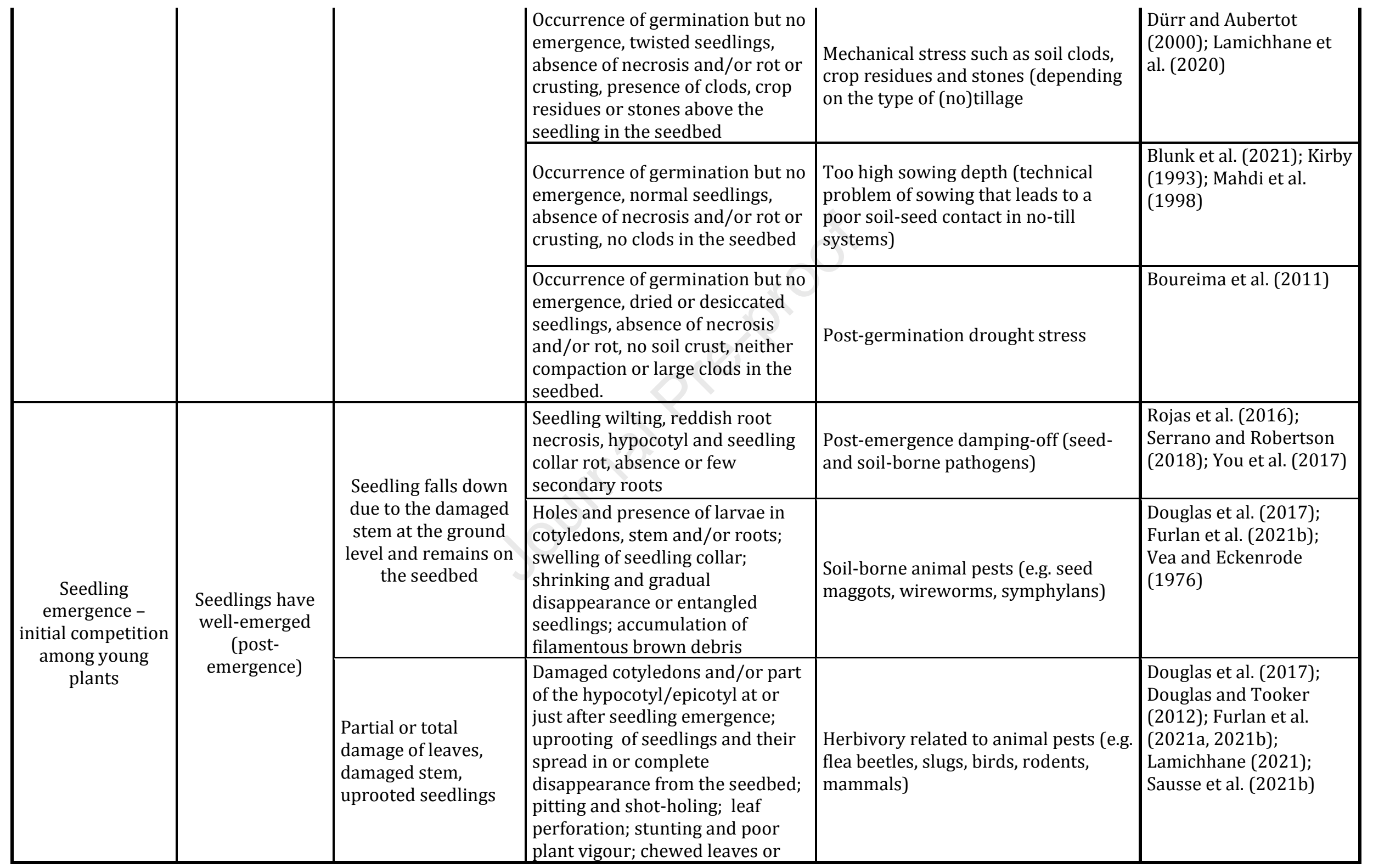




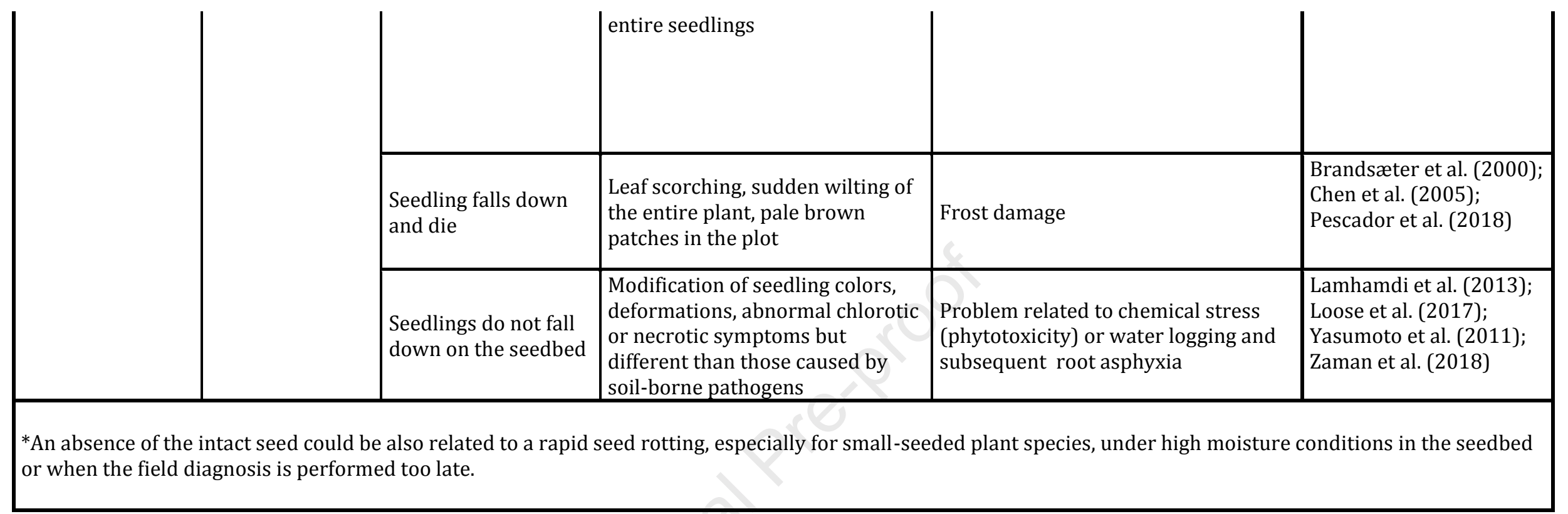




\section{Autotrophic phase}

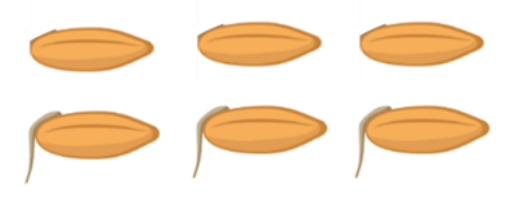

Sowing - Seed germination

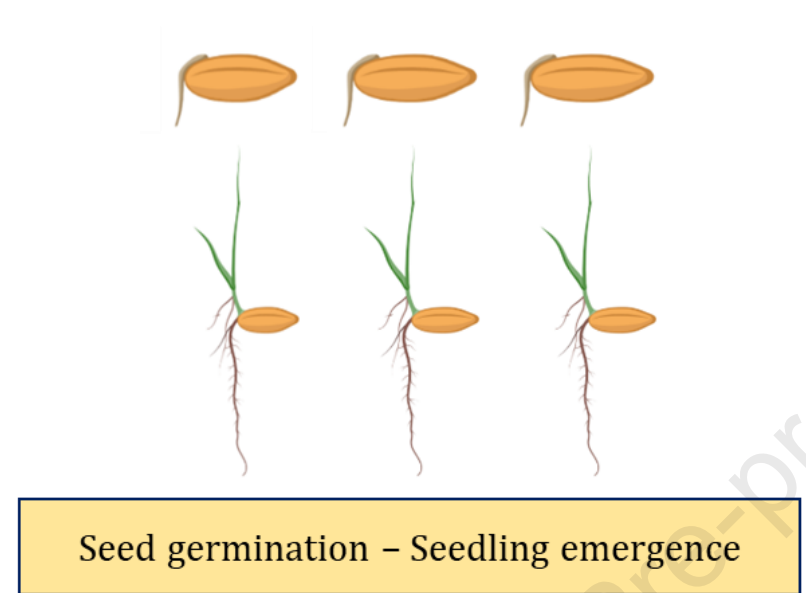

Seed germination - Seedling emergence

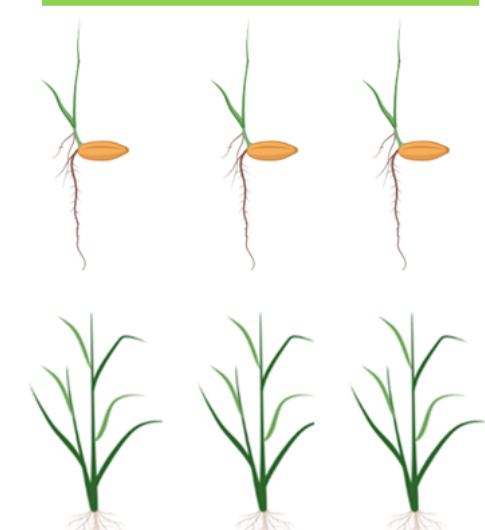

Seedling emergence - Initial competition among plants

Figure 1. Crop establishment is a phase that consists of three sub-phases viz. sowing to seed germination; seed germination to seedling emergence; and seedling emergence to initial competition among young plants. The former two sub-phases are heterotrophic (i.e. the radicle and seedling development relies on the seed reserves) while the last sub-phase is autrotrophic (i.e. the seedling has already developed true leaves that are capable to perform photosynthesis and, thus, do not depend anymore on seed reserves that are already exhausted at this stage). 
Figure 2. Poor field emergence of faba bean (a) and brown mustard (b) due to unknown reasons. Identification of the causes leading to non-emergence is a first step to better manage biotic and abiotic factors affecting seed germination and seedling emergence via best cropping practices.

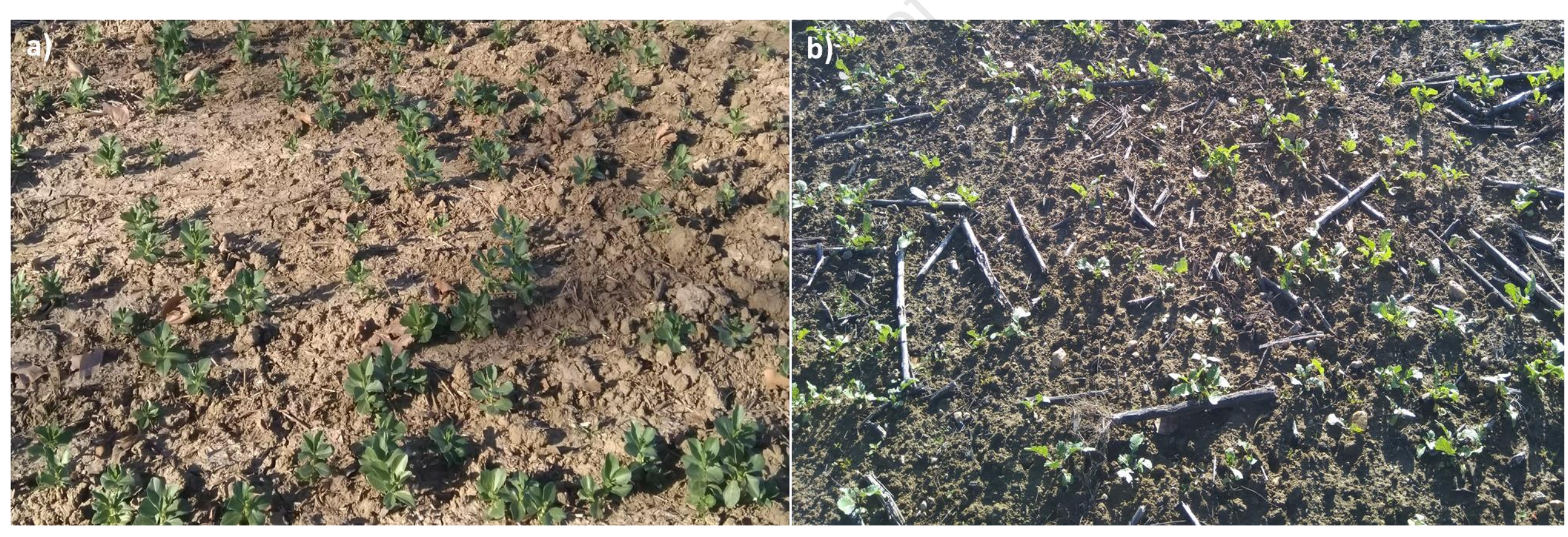


Figure 3. Seed predation due to slugs under directly sown soybean in a relay cropping system. These pests can cause partial (a) or total (b) seed predation when the sowing quality is not optimal (superficial sowing depth, poor soil-seed contact etc.).

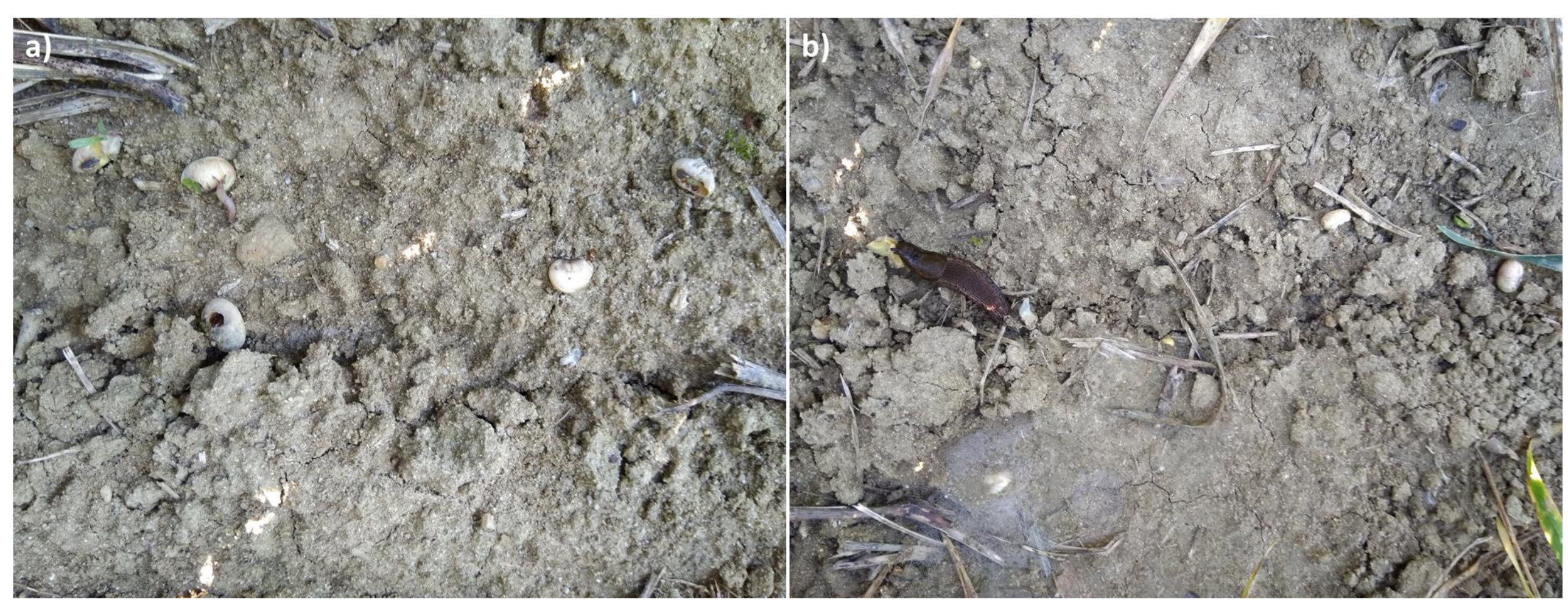


Figure 4. Characteristic symptoms of post-emergence seedling damage due to animal pests. Slug feeding (a), and cutting and uprooting by common wood pigeon (b) of soybean seedlings.

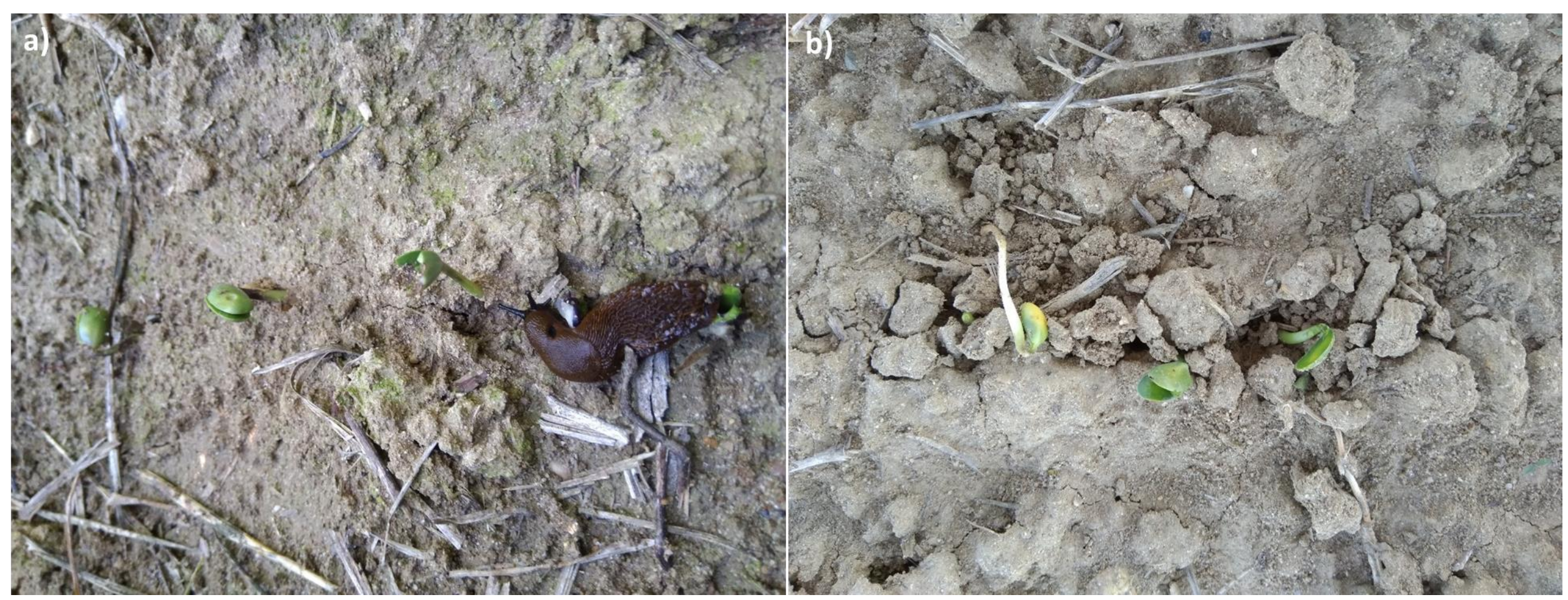


Figure 5. Characteristic symptoms of post-emergence seedling damage due to animal pests. Chewed cotyledons or the entire young leaves of soybean by European hare (a), and shot-holing of radish leaves by flea beetle (b).

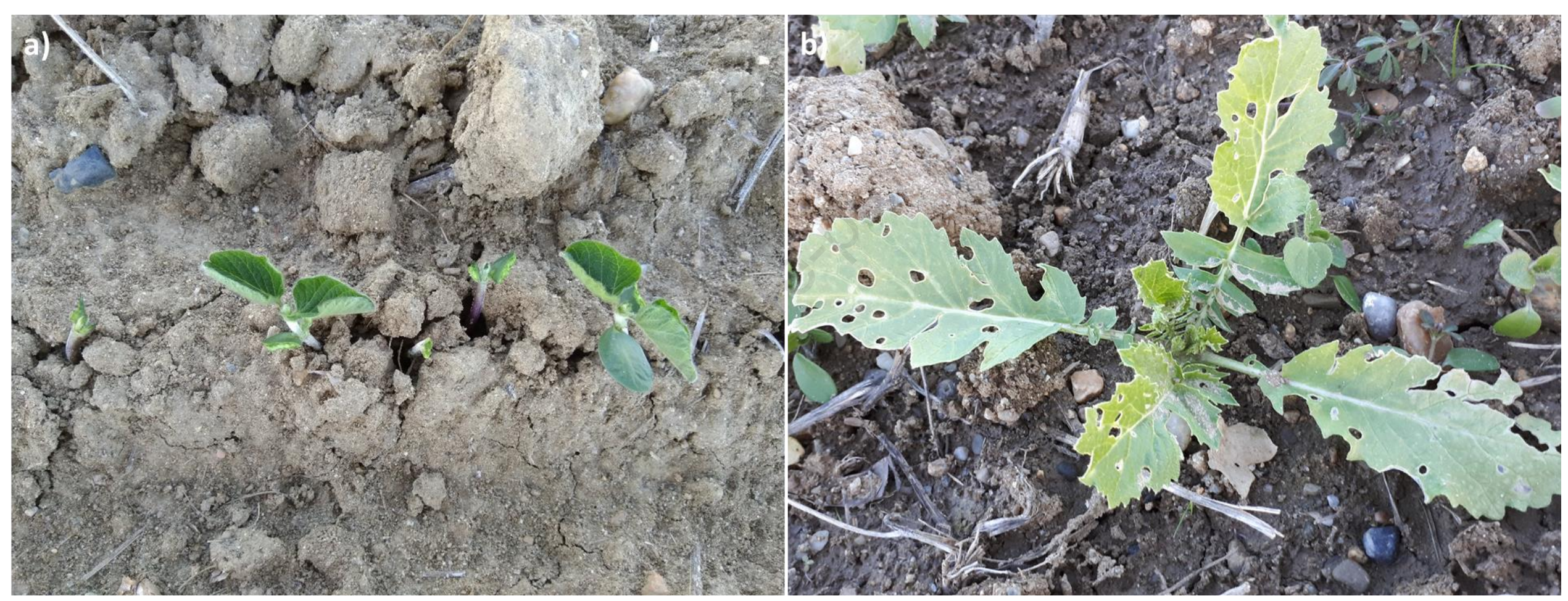


This is an editorial so there are no highlights. 


\section{Declaration of interests}

$\bigotimes$ The authors declare that they have no known competing financial interests or personal relationships that could have appeared to influence the work reported in this paper.

$\square$ The authors declare the following financial interests/personal relationships which may be considered as potential competing interests: 